\title{
Green areas and water management in residential developments in the European Western Mediterranean. A case study of Alicante, Spain
}

\author{
Alvaro Francisco Morote-Seguido and María Hernández Hernández (iD

\section{ABSTRACT}

The intense urbanization of the Mediterranean coast as a result of the development of residentialtourist activities since the 1960s, especially from the mid-1990s to 2008 , has generated new urban environments associated with extensive urban typologies. These include gardens linked to houses with outdoor spaces that are shared between all of the residents of the residential developments. The aim of this study is to determine the main characteristics of these new urban green spaces and their effect on domestic water consumption in Alicante (Spain). To do this, we analysed the characteristics that define these types of gardens (surface area, density, plant species and irrigation system) and determined their water needs using the Water Use Classifications of Landscape Species method. The main conclusions are that the increase in paved areas is one of the strategies to reduce water consumption in spaces where turf grass is the most common plant species. This is due to increased water prices and lack of water resources.

\section{ARTICLE HISTORY}

Received 12 August 2015

Accepted 7 July 2016

\section{KEYWORDS}

Gardens; water management; residential developments; Western Mediterranean

\section{Introduction}

Urban development is one of the main reasons for global growth in water consumption, which has tripled over the last 50 years (Gil et al., 2015). This trend has increased as a result of the surge in new urban typologies where outdoor uses are omnipresent (European Environment Agency, 2009; Morote \& Hernández, 2016a; Salvati, Ridolfi, Zambon, Serra, \& Saurí, 2015). The impacts of sprawling suburbs are well documented; energy and land consumption are often targeted as the main environmental problems (Couch, Petschel-held, \& Leontidou, 2007). However, in certain climates, water also enters the equation and becomes an issue of utmost importance for planners and managers as water-dependent elements in the form of gardens, swimming pools, etc. spread across landscapes due to sprawl (Askew \& McGuirk, 2004; Gössling, 2015; Morote, Saurí, \& Hernández, 2016). This process has characterized the European Mediterranean coastline (the French Côte D’Azur) and Florida (Fernández \& Barrado, 2011), along with large sections of the Spanish Mediterranean coastline (Burriel, 2008; Gaja, 2008) including the Balearic Islands, which for a long time has been affected by this progress, (Salvà, 2002), the Costa del Sol (Raya \& Benítez, 2002) and the coastline of Murcia (Monreal, 2001).

In Spain, "residential developments with outdoor communal areas" refer to residential areas located on the outskirts of urban spaces. These consist of a group of dwellings (semi-detached houses and blocks of apartments) with shared areas containing swimming pools, gardens, car parks, etc. This urban typology enables the construction of more houses, due to the fact that an urban development area has a shared outdoor area unlike detached houses (see Morote \& Hernández, 2016a). Thus, housing costs are reduced, and the homes can be bought by social groups with average buying power (see Vera, 1987). A similar urban model can be observed in other parts of the world. For example, this urban typology is known as "Countries" in Argentina (Arrigada \& Godoy, 1999) and "Gated Communities" in the USA and Canada (Billard and Madoré, 2005; Charmes, 2005).

In this paper, we analyse the green spaces of the residential developments in the new urban Spanish developments. In Spain, these green areas have become deeply connected with a development process that imitates the Anglo-Saxon model, which often includes a garden (Askew \& McGuirk, 2004; Hof \& Wolf, 2014). These have become one of the outdoor elements that consumes the most water resources due to the use of turf grass (Parés, March, \& Saurí, 2013; Robbins, 2012) or the introduction of Atlantic deciduous plant species that sometimes represent more than $50 \%$ of the total domestic water consumption in the house (Domene \& Saurí, 2006; Loh \& Coghlan, 2003). This 
creates new urban natural environments (Swyngedouw, 1999). The results obtained in this article allow for comparisons to be made with other regions of the world. In arid and semi-arid areas of the western US, watering the garden is the task that consumes the largest amount of water in a household - up to $50 \%$ of the total water consumption (St.

10 Hilaire, Spinti, Van Leeuwen, \& Smith, 2003; Timmins, 2002). In the case of Australia, authors such as Loh and Coghlan (2003) place this figure as high as $56 \%$ for private gardens in Perth. For the Metropolitan Area of Barcelona (Spain), Domene and Saurí (2006) it is calculated that, in the sum-

15 mer months, high-income villas allocated approximately 4.28 litres $/ \mathrm{m}^{2} /$ day to watering the garden, $49 \%$ of the total water consumed in the household.

Private urban landscapes are also inextricably connected to the processes of modernization and develop-

20 ment brought about by the interplay between water and urbanization (Swyngedouw, 2004). In Spain, for instance, the political ecological processes that have radically transformed the country's water environments follow the classic modernization path: from the dams and reservoirs that

25 allowed for the expansion of irrigation and hydroelectricity in the 1940s and 1950s to the inter-basin water transfers that added water flows for urban and mass tourist growth in the Mediterranean areas of the 1960s and 1970s. The most recent development is the construction of desali-

30 nation plants that provide for the new water demands that are linked to an increase of outdoor water use, associated with the urbanization boom of the 1990s and 2000 s (Swyngedouw, 2015, 2016). It is during this last period that we must place the expansion of private gardens as perhaps

35 the most recent beacon of urban modernity in the country. However, the collapse of the real estate market from 2007/08 onwards and recurring climatic hazards such as droughts combine to check water-based urban growth in such a way that threatens the very fabric of urban moder-

40 nity (Morote et al., 2016). Spain must face the risks and uncertainties of water-dependent urbanization models (Domene, Saurí, \& Parés, 2005; Fernández, Ordovás, \& Herrera, 2011; Garcia, Llausàs, \& Ribas, 2014; Padullés, Vila, \& Barriocanal, 2014a, 2014b), and it is therefore necessary

45 to increase knowledge of the characteristics of these environments and their role in urban water consumption.

Publications focused on water consumption associated with community gardens in residential developments (semi-detached houses or block of apartments) are tes-

50 timonial. There are similar studies that focus on urban forest growth and its impact on the water demand of residential landscapes, conducted by Lowry, Ramsey, and Kjelgren (2011), water demand in the outdoor areas in the neighbourhoods of Salt Lake County (USA) was analysed. 55 Studies of this type are not often conducted in Europe.
Existing studies have focused on the gardens of detached houses and, to a lesser extent, public green areas (Parés, 2005; Saurí, Parés, \& Domene, 2009). This lack of attention could be due to the interesting character of urban typology. They cannot be considered as strictly intensive typologies, given that they have outdoor spaces, but they cannot be considered extensive either, as they are common spaces shared between all household owners in a residential development. Another reason could be the limited surface area that was present until the Spanish real estate bubble in the mid-1990s - it is since then that this typology has expanded in peripheral urban areas and in regions of coastal tourism where residential-tourist activities are dominant. The shortage of this type of research in Europe and the intensity of the process in the European Mediterranean coastline justify interest in the selected area of study.

The objectives of this study are as follows: (a) to investigate the characteristics that define the gardens of residential developments differentiating the north and south coasts of Alicante; (b) to calculate the theoretical water consumption required by these urban environments; and (c) to determine what percentage of the total domestic water demand in villages and residential developments is linked to gardens. The initial hypothesis is based on a potential increase in water consumption in this area. This is the result of diffusion of the most extensive urban typologies, particularly where gardens are prevalent. We therefore, analysed the characteristics that define these types of gardens (surface area, density, plant species and irrigation system) and determined their water needs using the WUCOLS method (Water Use Classifications of Landscape Species).

This article is structured as follows. In the introduction, we have explained the meaning of these types of gardens and expressed the similarities of these new Mediterranean urban environments other semi-arid parts of the world in regards to their effect on water consumption. We then explain the study area and the method, emphasizing the importance of calculating the impact of these green areas on domestic water consumption to plan for current and future water demands. The "Results and Discussions" section is divided into two sub-sections. In the first, the characteristics of the gardens are determined (number and surface area of the garden, percentage of the total plot of land occupied by the garden, dominant plant species and irrigation system used). In the second sub-section, the theoretical water needs of the garden and the percentage of this demand in relation to the total amount of water supplied to the municipality are calculated. In the conclu- 105 sion, we demonstrate the predominance of turf grass and reflect on strategies for controlling water consumption. 


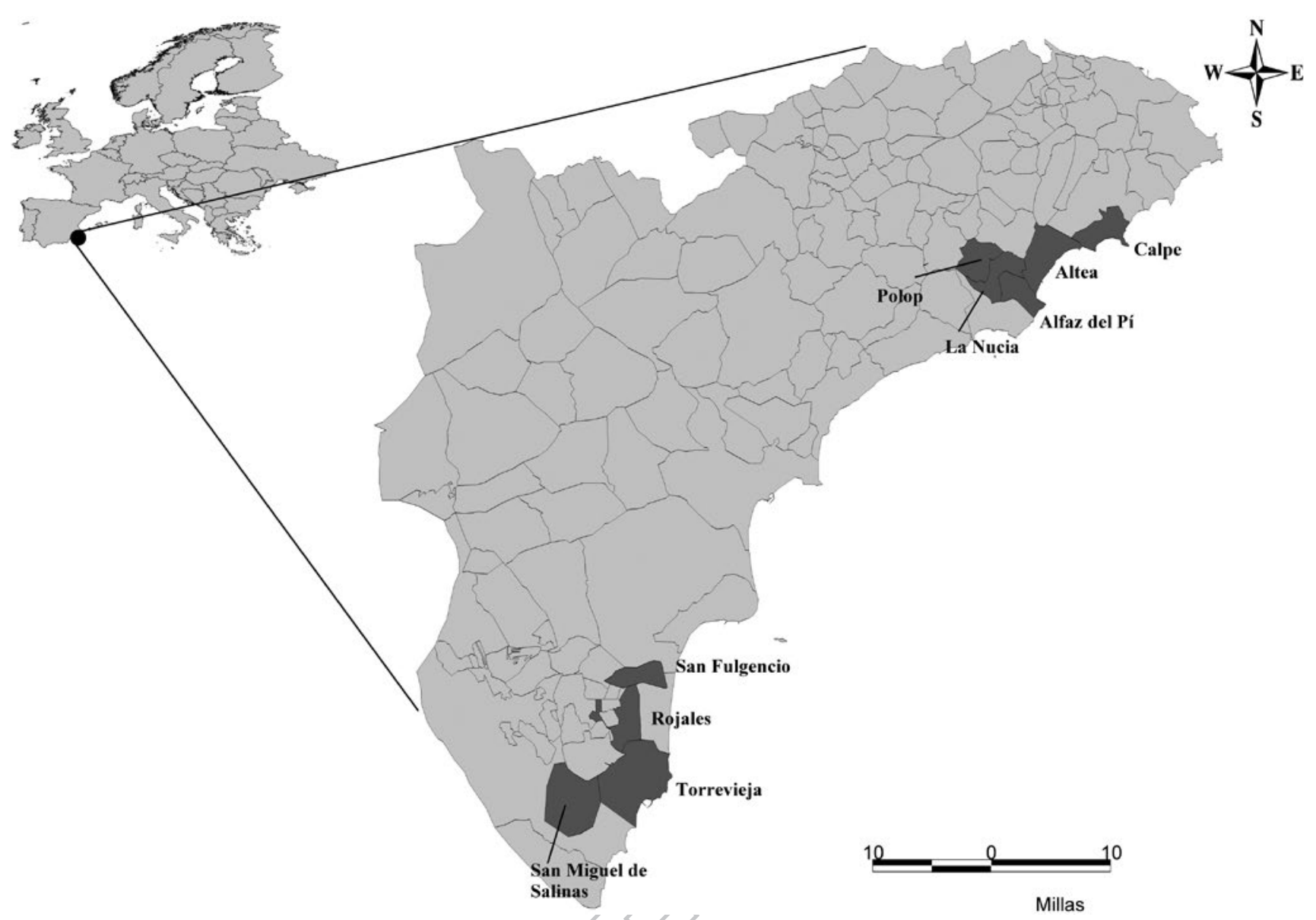

Figure 1. The study area on the coast of Alicante, Spain. Source: Compiled from the base mapping extracted from Geoportal IDEE (Infraestructura de Datos Espaciales de España). Authors.

\section{Study area}

The study area is the coast of Alicante (southeast Spain). Until the 1990s, this area enjoyed a relatively diversified productive base, including irrigated agriculture, the manufacturing of consumer goods and coastal tourism, primarily locates within emblematic centres of mass tourism such as Benidorm (Rico, Olcina, \& Saurí, 2009). However, since the late 1990s, a real estate bubble driven by the availability of cheap credit has absorbed larger and larger shares of the economic activity, as has occurred in most of the world (Burriel, 2008). Between 1997 and 2008, Alicante ranked third in Spain in the number of housing units built $(345,410)$, behind Madrid and Barcelona, but ahead of provinces with larger populations such as Valencia and Málaga (Hernández, Morales, \& Saurí, 2014; Rico \& Hernández, 2008). It is one of the areas around the world that showed the greatest increase of urbanization and tourism. For example, in Alicante the urban surface area in 1978 was 49,904,151 and 221,965,736 m² in 2013. In coastal cities, the loss of rural areas is as high as $80 \%$ (Rico \& Hernández, 2008; Hernández, Rico, \& Juárez, 2010). Moreover, detached houses currently occupy $57.5 \%$ of the total urban area, with semi-detached houses and blocks 25 of apartments occupying 13.4 and $5.1 \%$, respectively. This real estate boom is checked by the proliferation of semi-detached houses and apartment blocks, where community gardens are completely different (both size and typology of vegetation) to the private gardens of detached houses (see Morote \& Hernández, 2016a).

This real estate boom affects consumption and demand for certain natural resources, including water, especially due to the increased presence of Atlantic plant species (turf grass) that usually occupy the largest area of these spaces. Additionally, the lack of official statistical data for these new urban gardens and the scant attention given to research in these areas, both nationally and internationally, justifies the study of this topic, especially as the results may help with future planning of new urban spaces in regions such as the chosen study area, which are characterized by scarce water resources.

To study the relationships between green areas and residential developments in Alicante in detail, nine coastal municipalities, representative of dominant residential models, were selected. On the north coast, Calpe, Altea, 


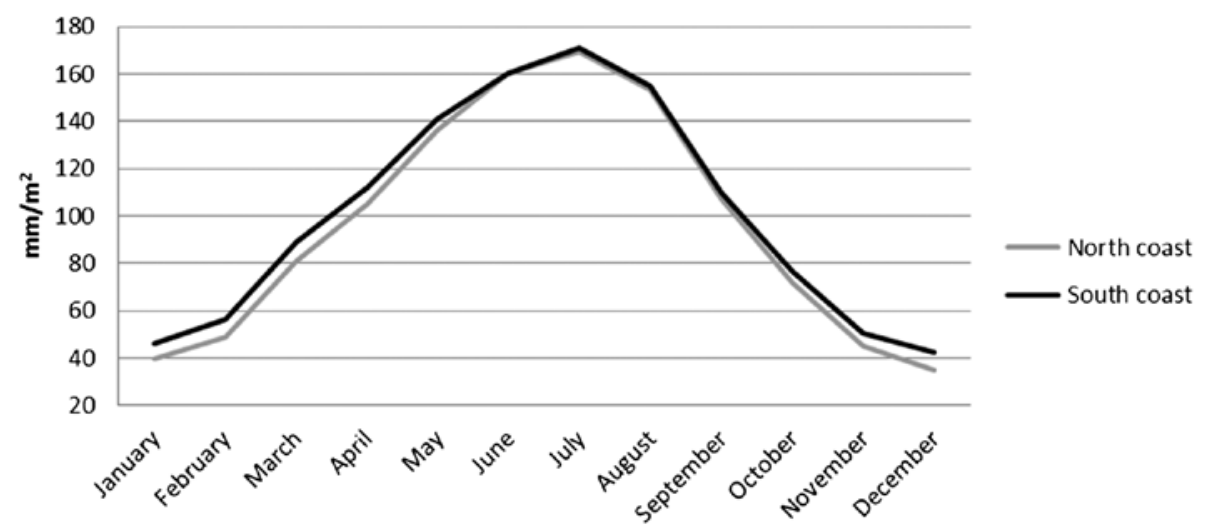

Figure 2. Evapotranspiration $\left(\mathrm{mm} / \mathrm{m}^{2}\right)$ from the north and south coast of Alicante. Source: Observatory of Altea (North coast of Alicante) (altitude: 210 m; UTM X: 754,487; UTM Y: 4,277,144; splindle: 30); Observatory of Almoradí (South coast of Alicante) (altitude: 74 m. UTM X: 695,435; UTM Y: 4,218,310; splindle: 30). Authors.

Polop, La Nucía and Alfaz del Pi were chosen, and the south coast (San Fulgencio, Rojales, Torrevieja and San Miguel de Salinas (Figure 1). Differences between these two areas are related to income levels, dominant urban typologies, housing characteristics, the history of urban residential uses, the intensity of the urbanization process and climatic conditions (see Morote \& Hernández, 2016a).

The real estate bubble and the massive arrival of European migrants also modified the urban configuration of Alicante as most growth took place on cheap land in the less developed south of the province, where immigrants chose to settle (see Huete, Mantecón, \& Mazón, 2008). The older (in terms of urbanization) and richer north expanded more moderately (Casado, 2006). The average disposable income per person in the province of Alicante is $14,500 € /$ year. Municipalities on the north coast reach values of approximately $16,000 € /$ year, whereas those in the south barely reach $13,000 € /$ year (Rovira, 2011). The real estate bubble also created growing polarization between north and south regarding housing typologies. Detached houses, often on large lots, were and continued to be dominant in the north, whereas in the south, smaller houses and condominiums were more common (Baños, 1999; Navalón, 1995). The urban residential uses in the north coast, beginning in the 1960s and 1970s, have followed a low-density pattern, whereas in the south, especially during the real estate bubble of the 2000s, the dominant model became that of the more concentrated condominium (Morote, 2014).

In terms of climate, the region is one of the driest in Spain. Average rainfall is approximately $356 \mathrm{~mm} /$ year according to the Meteorological Observatory of Ciudad Jardín in Alicante (Agencia Estatal de Meteorología, 2014). However, there are significant differences between the northern and southern coast. In the former, average rainfall is $500-600 \mathrm{~mm} /$ year, whereas in the latter, which is only
$40 \mathrm{~km}$ away, it is $200-300 \mathrm{~mm} /$ year; for example, the town of Torrevieja ( $260 \mathrm{~mm} /$ year). The low annual rainfall combined with high temperatures, especially in the summer where the average is $26^{\circ} \mathrm{C}$ (Gil \& Rico, 2007), means that evapotranspiration is substantially greater in the south. Average real evapotranspiration is $1151.97 \mathrm{~mm} /$ year in the north (Observatory of Altea) and $1208.95 \mathrm{~mm} /$ year in the south (Observatory of Almoradí) (Figure 2).

\section{Methodology}

In this study, the working methods were as follows: photogrammetric interpretation of satellite images from 2014 of the nine towns selected from the study area, visits to residential developments, surveys given to owners of 50 garden companies, the WUCOLS method and analysis of data provided by the water company. The choice of the number of urban developments is related to the method used, photogrammetric interpretation, that allow us identify differences among urban development in the 55 nine studied municipalities (i.e. differences in period of construction, surface of the urban development differentiating between the houses and outdoor uses, type of vegetation, vegetation density and main plant species, etc.).

Photogrammetric interpretation involved the following activities:

(a) The first step was mapping the total surface area $\left(\mathrm{m}^{2}\right)$ of all green spaces of the residential developments in the study area (The north and south coast of Alicante). We used a GIS (Geographical Information System, GvSIG 1.12). The mapping process was carried out by using the orthophotos from the Air National Orthography Plan. These were taken by the Spanish National Geographic 70 Institute in 2014. 
(b) The second step was visiting 50 residential developments during 2014 to discover the main characteristics of the gardens and the urban

Through the selection of a series of test spaces, the fieldwork enabled us to confirm the accuracy of the results obtained in the cartographic treatment and to verify the irrigation systems used. The main plant species analysed were turf grass, trees and shrubs. Once the main characteristics of gardens were identified (area and elements that integrate the garden, density, vegetation and the water efficiency), we proceeded to calculate the garden water needs (GWN) that were used in many studies. See for example Domene and Saurí (2003) or Contreras, González, 55 López, and Calvo (2006).

To determine whether gardens were irrigated according to the agronomical requirements of species planted, we used the garden coefficient (GC) method developed in California (Costello, Matheny, \& Clark, 2000) by applying the WUCOLS method. It is based on the so-called GC, which reflects the relationship between reference evapotranspiration ( $\left.\mathrm{ET}_{0}\right)$ and the evapotranspiration of a particular garden (GET). Diversity in species planted (PSC), garden densities and water efficiency (WE) is also required. The formula for estimating the water requirements of gardens can be summarized as follows: GWN = (GET - P) /WE (Table 1).

To calculate the GWN, we firstly calculate the GC $(G C=P S C \times G D C)$. The former is given a value between 0 and 1 (1 representing plants with the highest water needs). The plant species in a garden are placed in groups with similar characteristics, which are assigned a single coefficient (Table 2). Secondly, we proceeded to calculate the garden's evapotranspiration $\left(\mathrm{GET}=\mathrm{ET}_{0} \times \mathrm{GC}\right)$. The relative values of $\mathrm{ET}_{0}$ and rainfall were obtained from the Agencia Estatal de Meteorología (AEMET) website. Given the large variety of potential species and vegetation density, the GC must take into account other factors such as the type of formation (trees, shrubs or turf grass) and the relationship established between density and leaf size. Gardens with higher GDC and larger leaf size will have higher $\mathrm{ET}_{0}$ than lower density gardens (Table 3). After having calculated the values of GET, rainfall and WE, we found the GWN to be $902 \mathrm{~mm} /$ year $/ \mathrm{m}^{2}$ on the north coast and $1210 \mathrm{~mm} /$ year/ $\mathrm{m}^{2}$ on the south coast.

The last step was to use real data on the water supplied to the towns. This was obtained from the company Hidraqua, Gestión Integral de Aguas de Levante SA. The total water consumption in 2014 in the community areas of the

Table 1. Formulas used to calculate the Garden water needs (GWN).

\begin{tabular}{lcc}
\hline & North Coast & South Coast \\
\hline (a) GC=PSC $\times$ GDC & & \\
PSC: Plant species coefficient & .91 & .92 \\
GDC: Garden density coefficient & 1.0 & 1.0 \\
GC: Garden coefficient & .91 & .92 \\
& & \\
(b) GET = ET ${ }_{0} \times$ GC & & \\
ET: Evapotranspiration (mm/year) & 1151.97 & 1208.95 \\
GC: Garden Coefficient & \multicolumn{1}{c}{.91} & .92 \\
GET: Garden's Evapotranspiration (mm/year) & 1048.30 & 1112.23 \\
& & $\Lambda$ \\
(c) GWN = (GET - P)/WE) & & \\
GET: Garden's Evapotranspiration (mm/year) & 1048.30 & 1112.23 \\
P: Average annual rainfall (mm/year) & 461.61 & 325.35 \\
WE: Watering Efficiency (\%) & 65 & 65 \\
GWN: Garden water needs (mm/year/m²) & 902 & 1210 \\
\hline Source: Costello et al. (2000). Interpretation conducted by the authors.
\end{tabular}


Table 2. Plant species coefficients.

\begin{tabular}{lc}
\hline Types of plants & PSC \\
\hline Succulents & $.2-.3$ \\
Fruit trees & $.6-.7$ \\
Trees & $.6-.8$ \\
Ornamental bushes & $.7-.8$ \\
Flowers & $.8-1.0$ \\
Turf grass & 1.0 \\
Orchard & 1.0 \\
\hline
\end{tabular}

Source: Pujol (2000).

Table 3. Garden density coefficients.

\begin{tabular}{lc}
\hline Density & GDC \\
\hline Low & $.5-.9$ \\
Medium & 1.0 \\
High & $1.1-1.3$ \\
\hline
\end{tabular}

Source: Costello et al. (2000).

50 residential developments was also used. The data made it possible to know the theoretical percentage that represents the water consumption of the gardens.

\section{Results and discussions}

The results and discussions are presented in two separate sections according to the objectives of the paper. Results about the characteristics of the gardens are given in the first section (objective A). The theoretical water consumption required by these urban environments (objective B) and the percentage of the total domestic water demand 10 in the villages and in residential developments are represented by the gardens (objective $C$ ) and presented in the second section.

\subsection{Characteristics of green areas in residential developments}

The photogrammetric interpretation of the satellite images and subsequent fieldwork enable us to establish the main characteristics of the gardens related to following factors: (a) the number of residential developments; (b) the elements that are part of the plot of land; (c) the total surface area of the green spaces and the percentage of land occupied by the gardens; (d) the dominant species; and (e) the vegetation density.

First, the total number of residential developments in the 9 municipalities is 1654. A differentiated analysis of the coast (north and south) shows an incipient differentiation: a slight concentration in the most southern sector, where $61 \%$ of the total numbers of residential developments are located. However, greater heterogeneity between sectors can be seen in terms of the number of residential developments with landscaped spaces (Figure 3). Of the 653 residential developments on the northern coast, $66 \%$ have a garden. In the southern sector (1001 residential developments), however, only $47 \%$ have green areas (Table 3).

A second characteristic is the elements that are part of the plot of land and the garden's percentage of the total area (Table 4). It is also important to note that these houses have small private outdoor spaces (approximately $10 \mathrm{~m}^{2}$ ) in the form of a patio garden, which often has paved areas, flowerpots and even trees or hedges (Morote, 2014). Its limited surface area and dominant vegetation typologies result in an insignificant impact on water consumption. Residential developments on both coasts have a similar number of houses (an average of 61 houses).
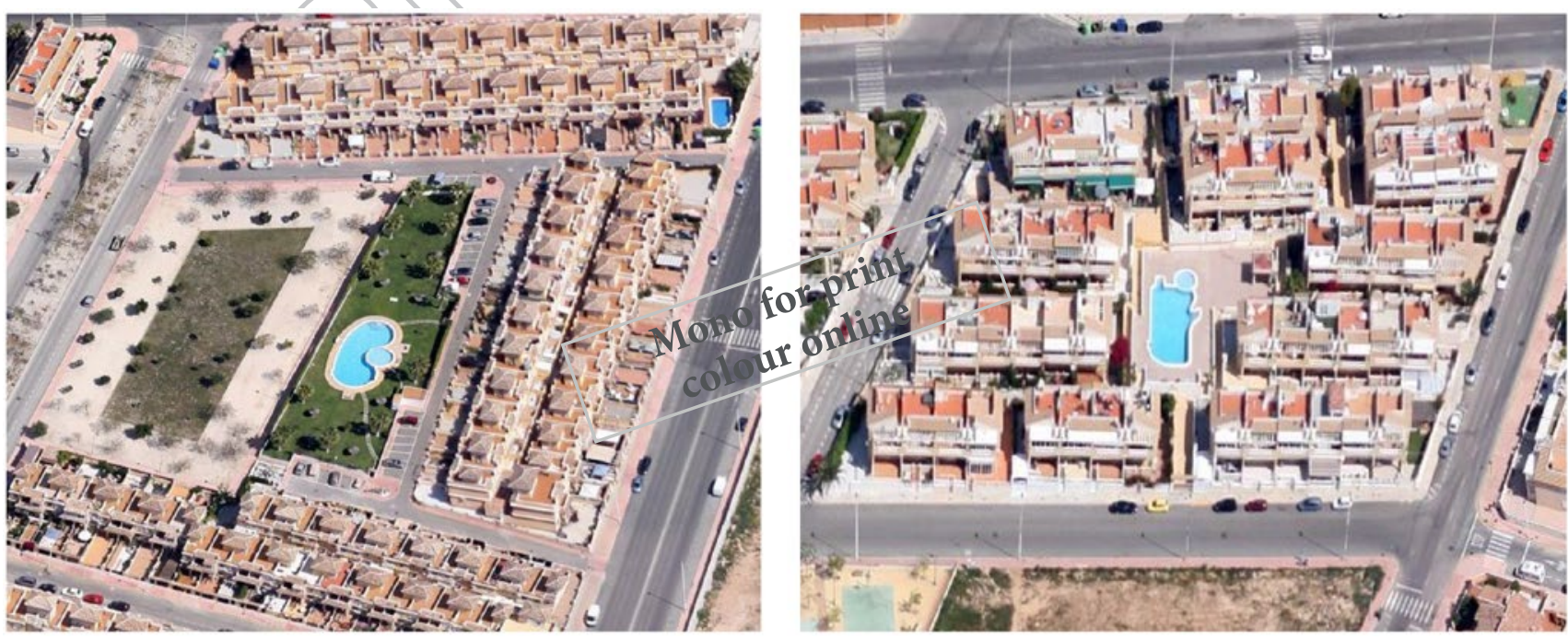

Figure 3. Residential developments with and without gardens in the South of Alicante. Source: https://www.google.es/maps. 
Table 4. Main characteristics of residential developments.

\begin{tabular}{|c|c|c|c|c|c|}
\hline Villages & $\begin{array}{l}\text { No. of Residential } \\
\text { developments }\end{array}$ & $\begin{array}{l}\text { No. of Residential } \\
\text { developments with } \\
\text { gardens }\end{array}$ & $\begin{array}{c}\% \text { residential } \\
\text { developments with } \\
\text { gardens }\end{array}$ & $\begin{array}{l}\text { Average size of the } \\
\text { gardens }\left(\mathrm{m}^{2}\right)\end{array}$ & Total garden area $\left(\mathrm{m}^{2}\right)$ \\
\hline Alfaz del Pi & 177 & 148 & 84 & 736 & 108,982 \\
\hline Altea & 146 & 110 & 75 & 946 & 104,137 \\
\hline Calpe & 225 & 100 & 44 & 653 & 65,309 \\
\hline La Nucía & 81 & 57 & 70 & 795 & 45,327 \\
\hline Polop & 24 & 13 & 54 & 1253 & 16,290 \\
\hline North coast & 653 & 428 & 66 & 876 & 340,045 \\
\hline Rojales & 242 & 86 & 36 & 408 & 35,108 \\
\hline San Fulgencio & 53 & 16 & 30 & 767 & 12,268 \\
\hline S. Miguel de Salinas & 57 & 23 & 40 & 610 & 14,035 \\
\hline Torrevieja & 649 & 349 & 54 & 820 & 286,512 \\
\hline South coast & 1001 & 474 & 47 & 651 & 347,923 \\
\hline
\end{tabular}

Source: Data compiled from photogrammetric interpretation by the authors.

Table 5. Size of the residential developments and plot elements.

\begin{tabular}{|c|c|c|c|c|}
\hline & \multicolumn{2}{|c|}{ North coast } & \multicolumn{2}{|c|}{ South coast } \\
\hline & $\mathrm{m}^{2}$ & $\%$ & $\mathrm{~m}^{2}$ & $\%$ \\
\hline Garden & 876 & 10 & 651 & 8 \\
\hline Paved area & 1370 & 16 & 1562 & 18 \\
\hline Pool & 126 & 1 & 99 & 1 \\
\hline Houses & 5370 & 62 & 5321 & 63 \\
\hline Others & 947 & 11 & 189 & 9 \\
\hline Total & 8689 & 100 & 8422 & 100 \\
\hline
\end{tabular}

Source: Data compiled from photogrammetric interpretation by the authors.

The third element considered was the dimensions of the land plots. The average size of a plot is similar between the two coasts: $8689 \mathrm{~m}^{2}$ on the northern coast and $8442 \mathrm{~m}^{2}$ on the southern coast (Table 5, Figures 4 and 5), ln the case of residential developments with green areas, the garden's percentage of the total surface area is $10 \%$ on the northern and $8 \%$ on the southern coast. Moreover, there is a prominence of paved spaces in this typology. On both coasts, these spaces are larger in percentage than green spaces - the figure is slightly higherin the south (18\%) than in the

10 north (16\%). However, differences start to appear when measuring the average size of a garden. The average garden size on Alicante's coast is $763 \mathrm{~m}^{2}$, although there are notable differences between the two coastal sectors. The average garden size is slightly greater in the north $\left(876 \mathrm{~m}^{2}\right)$

15 than in the south $\left(651 \mathrm{~m}^{2}\right)$. These values reveal contrasting realities between the two coastal areas. In the north, it is common for residential developments to have landscaped areas measuring over $1000 \mathrm{~m}^{2}$ on average. In the south, there are few areas over $700 \mathrm{~m}^{2}$.

20 The differences between the two coastal regions regarding number and surface area of these landscaped spaces can be explained by the following factors: (a) the dominant model and urban typology; (b) the process of introduction and diffusion of residential-tourist activities; (c) the owners' level of income; and (d) climatic conditions. The land urban model that characterizes Alicante's coast is defined by the predominance of more extensive

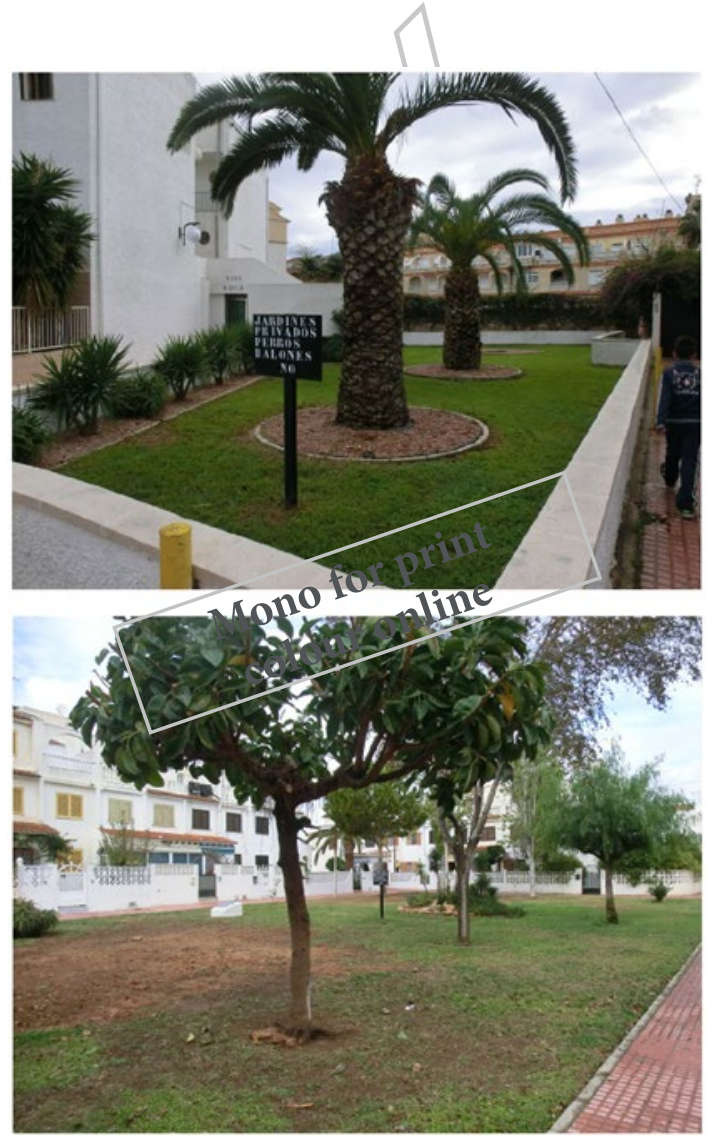

Figure 4. Shared gardens in Torrevieja. Source: Authors.

typologies in the northern region, where detached houses with a garden and swimming pool are more prevalent than on the southern coast, where residential developments of terraced and semi-detached houses are more common (see Morote \& Hernández, 2014, 2016a). The introduction of residential-tourist activities also influences the size of the urban outdoor spaces. The outdoor spaces built in the 1960s and 1970s have the largest dimensions (especially in the form of apartments in the northern coastal region and semi-detached and terraced houses in the southern coastal region) (Navalón, 1995). The size of these spaces 


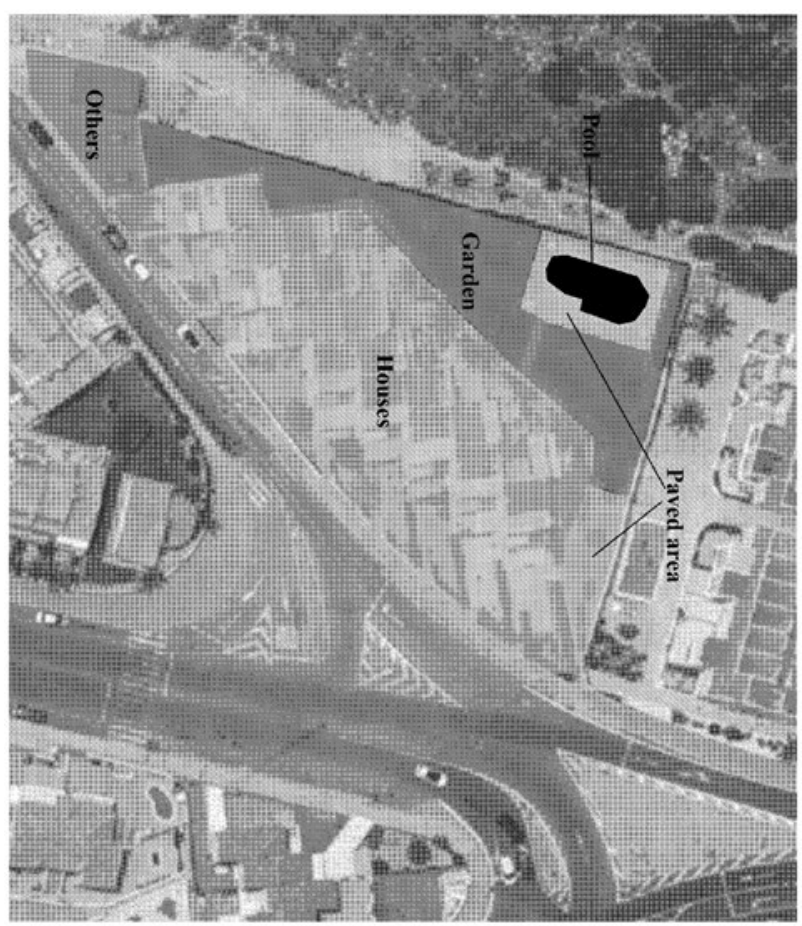

$$
\int_{0}^{\vec{p}}
$$

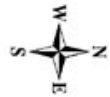

Figure 5. Example of residential development in Torrevieja. Source: Authors.

was significantly reduced in those built during the real estate bubble from 1995 to 2007 (Burriel, 2008). This process, which to a large extent coincided with the high demand for houses in coastal areas due to migration of retired or early retired people from central and northern Europe (Casado, 2008), led developers to build a larger number of houses per unit of urban development area.

The third differentiating element is the income of the families: the higher the income, the larger the plots of the developed areas and, in particular, the spaces for outdoor uses. Data from the Socio-Commercial Atlas of the

15 Valencian Region (Rovira, 2011) support this claim. The last element is the climate. Both the shortage of rainfall and the somewhat high level of evapotranspiration in this territory have an impact on the landscaped area and paved spaces. The scarcity of rainfall and the lower level of income have resulted in smaller gardens and, in particular, smaller areas with vegetation and larger paved areas. In some cases, especially in developments built after the late 1990s, paved areas have completely replaced landscaped areas (see Morote \& Hernández, 2016a, 2016b).

Turf grass is the most common species of vegetation in the landscaped spaces, representing approximately $60 \%$ of the total landscaped area, followed by trees (26\%) and
Table 6. Main plant species (\%).

\begin{tabular}{lcc}
\hline & North coast & South coast \\
\hline Turf grass & 58 & 60 \\
Trees & 31 & 22 \\
Ornamental bushes & 11 & 18 \\
\hline
\end{tabular}

Source: Data compiled from photogrammetric interpretation by the authors.

shrubs (14\%) (Table 6). This means that the GC for water needs is close to 1 - the highest value. As opposed to the characteristics considered above, there are no large variations between the two coastal regions. The most significant contrasts are in the formations of trees and shrubs and the garden surface area. The large percentage of area taken up by turf grass confirms the existence of new urban environments in these urban typologies. Their diffusion is associated with a high percentage of decorative vegetation compared to native plants (Robbins, 2012). The presence of decorative vegetation is also due to adaptation of the landscape for leisure activities for adults and, in particular, children. Larson, Casagrande, Harlan, and Yabiku (2009) argued that xeric gardens can be perceived by parents as being potentially dangerous for their children, given the existence of species with thorny and coriaceous leaves. Thus, in these houses a garden without succulent plants, cactus or large spaces of turf grass is viewed positively.

\subsection{The theoretical water demand of the gardens}

Determining the theoretical water demands of the green areas and their impact on domestic water consumption is essential for managing and planning both current and future water policies. In the province of Alicante, this requirement is even more important given the intense residential expansion experienced on the coast over the past 15 years and the structural lack of water resources, which means that a high percentage of the demand is covered through water transfers from other regions (Rico et al., 2009).

The theoretical water needs of the urban environments in the 9 municipalities of the study area have been estimated at an average of $902 \mathrm{~L} / \mathrm{m}^{2} /$ year on the northern coast and $1210 \mathrm{~L} / \mathrm{m}^{2}$ year on the southern coast according to the method of Costello et al. (2000). These high consumptions are due to the dominant species, turf grass, which has a high PSC (1) and occupies approximately $60 \%$ of the landscaped area.

The second element that we analysed was the theoretical water consumption per garden. By taking into account the average surface area of the garden and the water needs of the plants per surface unit, we estimated the volume of water required per year by these urban environments is $790 \mathrm{~m}^{3} /$ year in the northern sector and $788 \mathrm{~m}^{3} /$ year in the southern sector. The similarity of these 
figures is due to the slightly higher level of evapotranspiration in the south. However, the differences in climate are somewhat neutralized by the smaller surface areas of the 5 gardens in the southern coast $\left(651 \mathrm{~m}^{2}\right.$ compared to $876 \mathrm{~m}^{2}$ in the north). These volumes of water are notably higher than those required by the gardens of detached houses, which use $203 \mathrm{~m}^{3} /$ year in the north and $25 \mathrm{~m}^{3} /$ year in the south (see Morote \& Hernández, 2016a). This difference

10 can be explained by the larger surface of the gardens and the diversity of species. Turf grass is the dominant species in these shared green areas, whereas Mediterranean vegetation, with a low species coefficient (.3), and large paved areas (especially on the southern coast) are domi-

15 nant in the gardens of detached houses. This significantly reduces the theoretical water requirement of the plants (see Morote \& Hernández, 2014). At first, and according to the figures mentioned above, it may seem that shared gardens have a much greater impact on domestic water

20 demand than the gardens of detached houses. However, these consumptions represent the total consumption of all of the houses in the residential development and their residents. In the study area, an average residential development has 61 houses and approximately 150 residents.

25 According to these figures (garden water demand per year and average number of houses), each house would theoretically require $36 \mathrm{~L} /$ day ( $16 \mathrm{~L} /$ inhabitant/day) on the northern coast and $35 \mathrm{~L} /$ day $(15 \mathrm{~L} /$ inhabitant/day) in the south for the garden. As a result, the use of water per dwell-

30 ing is lower but the social repercussions are higher, which is understood by the users of the residential development's outdoor areas.

Finally, we analysed the total theoretical water consumption required for the irrigation of the gardens by 35 residential development and by municipality and its percentage as part of the total domestic water consumption. We obtained data from water meter counters provided by the water companies in the community areas in 2014 . It was found that total water consumption is $1225 \mathrm{~m}^{3} /$ year.

40 This reported consumption covers all uses (gardens, pools, water for the cleaning of common areas, ornamental fountains, etc.). With our estimation of the demand of water for these gardens $\left(790 \mathrm{~m}^{3} /\right.$ year in the north and $788 \mathrm{~m}^{3} /$ year in the south coast), we estimated that these green

45 areas could account for approximately $64 \%$ of the total water consumption of communal areas if they are irrigated according their water necessities.

Again, the highest volume of water consumption for the irrigation of community gardens was found in the 50 southern region $\left(420,987 \mathrm{~m}^{3} /\right.$ year). However, these figures conceal a highly contrasting situation. The municipality of Torrevieja consumes approximately $82 \%$ of the total volume $\left(346,680 \mathrm{~m}^{3}\right)$, whereas other municipalities in the south, where residential developments either lack green areas or have areas that are very small, have much 55 lower levels of consumption. On the northern coast, total consumption is $306,721 \mathrm{~m}^{3} /$ year and there is a much lower level of polarization between municipalities. Two of the towns (Alfaz del Pi and Altea), which are located on the beachfront and have experienced the introduction of residential-tourist uses in the 1960 s, account for $63 \%$ of the total consumption. The others, with later residential-tourist developments or with a predominance of extensive typologies (detached houses), have lower consumption.

It was also important to establish the percentage of 65 consumption of these gardens in relation to the total volume of municipal water consumption. Based on data supplied by the drinking water supply company (Hidraqua, Gestión Integral de Aguas de Levante SA) for 2014, the average percentage is $4-5 \%$ in the municipalities on the northern coast. For example, Alfaz del Pi and Polop require 5 and $4 \%$ of the total municipal consumption, respectively, to irrigate the gardens of the residential developments. These figures are below $4 \%$ on the southern coast ( $3 \%$ in Rojales and $2 \%$ in San Fulgencio). It is important to highlight that this consumption is theoretical. If we compare the results with those of others studies, we observe that real water consumption of the green areas is lower than the theoretical water need (see Domene et al., 2005; Parés, Domene, \& Saurí, 2004; Parés et al., 2013).

\section{Conclusions}

The intense development of the Spanish Mediterranean coast since the 1960s, and especially during the real estate bubble (1990s and 2000s), has resulted in the creation of new urban natures (gardens and swimming pools). Gaining a better understanding of this phenomenon is essential because of their impact on urban consumption in areas where there is a shortage of water resources due to climatic conditions, that have been accompanied by an increase in both agricultural and urban demand since the 1960s (March, Saurí, \& Rico, 2014). This is of particular interest given the lack of research on these issues, especially those focusing on green areas.

These reduced landscaped spaces with limited vegetation are aimed at reducing the costs associated with the maintenance of gardens where turf grass is the predominant plant species (approximately $60 \%$ of the total). This percentage is significantly higher than that of territories in Australia and the USA (with values of at least $30 \%$ ) with similar climate conditions, as corroborated by publications on private gardens (detached houses) by Timmins (2002), Loh and Coghlan (2003) or Larson et al. (2009). The presence of turf grass in the detached houses of the Spanish Mediterranean increases in line with rainfall levels. In north-east Spain, in the Metropolitan Area 105 
of Barcelona, turf grass represents $29 \%$ of garden areas in middle-income homes, and up to $49 \%$ in high-income homes (Domene \& Saurí, 2003). Percentages of approximately $30 \%$ are given in the research conducted by Garcia (2012) and Padullés (2015) in Girona.

The high level of evapotranspiration (especially in summer) and the shortage of water (below $300-400 \mathrm{~mm} /$ year) increases the water need of this Atlantic species. The increase in water prices in the past few years (they nearly

10 doubled between 2007 and 2013) placed Alicante's coastal towns amongst the most expensive in Spain (average price of $2 € / \mathrm{m}^{3}$ ) (Hernández et al., 2014), and the application of different prices according to levels of consumption (penalizing high use) has led to the reduction of land-

15 scaped spaces and the introduction of large paved areas on the southern coast (see Gil et al., 2015). This strategy is more common for homeowners with lower income who are reducing water consumption in the study area (see Morote \& Hernández, 2016b). In this sense, the increasing use of paved areas reduces the costs associated with the maintenance of the garden, especially those linked to water consumption (Garcia, 2014).

This research could improve the knowledge of the characteristics of water management in private green areas in the European Mediterranean region. Laws that regulate planning and management uses have given scant consideration to the relationship of new uses with water demand and the implications that these new uses would have on the demands for water. In many cases, actions

30 have been directed more to ensure an increase in water resources assuming regular demand. For example, in the case of drought, the actions taken include the prohibition of certain high-impact practices, such as watering gardens and filling swimming pools.

35 Perhaps the most important lesson to be learnt from the Alicante case is the impact of the different urban residential typologies on water consumption generated by outdoor residential uses, such as the gardens of residential developments. In this way, Alicante is much like other tourist areas of the world that lack water resources, such as some territories of Australia or the USA. To sum up, the key message is that climate migrants have fuelled the housing market in coastal regions of Spain and triggered a sharp increase in water demand due to their preferred turf grass areas. A better understanding of these features would help to improve our knowledge of the changing nature of urbanization in areas where sprawling urbanization has become widespread, and it would help us understand the environmental impacts of this sprawl. Additionally, it is important to increase the knowledge of urban green space to account for the consequences of climate change and the increasing frequency of serious droughts and the general lack of water resources. This is one result that should be taken into account in the planning of future European residential areas.

\section{Acknowledgements}

The results presented in this article are part of three research studies. The first, entitled "Urbanisation and water metabolism in the coast of Alicante: Analysis of trends for the 2000-2010 period" was funded by the Spanish MINECO under grant number CSO2012-36,997-C02-02. The second, entitled "Uses and management of non-conventional water resources in the coast of Valencia and Murcia as an adaptation strategy to drought" was funded by the Spanish MINECO under grant number CSO2015$65,182-C 2-2-\mathrm{P}$. The third is part of a $\mathrm{PhD}$ research grant funded by the Spanish Ministry of Education. The authors are also grateful for the data provides for the company Hidraqua, Gestión Integral de Aguas de Levante S.A. (Asunción Martínez) and Aguas Municipalizadas de Alicante, Empresa Mixta, S.A. (Francisco Bartual, Antonio Ivorra and Francisco Agulló).

\section{Disclosure statement}

No potential conflict of interest was reported by the authors.

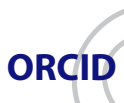

María Hernández Hernández (iD) http://orcid.org/0000-00028823-0083

\section{References}

Agencia Estatal de Meteorología. (2014). Datos climatológicos. Retrieved from http://www.aemet.es/es/serviciosclimaticos/ datosclimatologicos

Arrigada, I., \& Godoy, L. (1999). Seguridad Ciudadana y Violencia en América Latina: diagnóstico y políticas en los años noventa. Santiago de Chile: División de Desarrollo Social, CEPAL.

Askew, L. E., \& McGuirk, P. M. (2004). Watering the suburbs: distinction, conformity and the suburban garden. Australian Geographer, 35, 17-37. doi:10.1080/0004918024000193702

Baños, C. (1999). Modelos turísticos locales. Análisis comparado de dos destinos de la costa blanca. Investigaciones Geográficas, 21, 35-58. http://dx.doi.org/10.14198/INGEO1999.21.02

Burriel, E. (2008). La década prodigiosa del urbanismo español (1997-2006). Scripta Nova, XII, 270. Retrieved from http:// www.ub.es/geocrit/sn/sn-270/sn-270-64.htm

Casado, M. (2006). Retiring to Spain: An analysis of difference among North European nationals. Journal of Ethnic and Migration Studies, 32, 1.321-1.339.

Casado, M. A. (2008). Leisure lifestyles, social capital and international retirement migration: a research framework. In C. Balkir (Ed.), Uluslararasi Emekli Gocunun Ekonomik ve Sosyal Etkiler, Antalya Ornegii.

Charmes, E. (2005). La vie périurbaine face à la menace des gated communities. Paris: L'Harmattan.

Contreras, F., González, A., López, J., \& Calvo, A. (2006). Estimated water needs for species of garden in the region of Murcia: Adaptation of WUCOLS and use of agricultural information system of Murcia. Technical paper in III Jornadas Ibéricas de Horticultura Ornamental, Almería, Spain. 
Costello, L. R., Matheny, N. P., \& Clark, J. R. (2000). A guide to estimating irrigation water needs of landscape plantings in California. The landscape coefficient method and WUCOLS III. Sacramento, CA: University of California, Cooperative Extension. Retrieved from http://www.water.ca.gov/ wateruseefficiency/docs/wucols00.pdf

Couch, C., Petschel-held, G., \& Leontidou, L. (2007). Urban sprawl in Europe: Landscapes, land-use change and policy. London: Wiley-Blackwell.

Domene, E., \& Saurí, D. (2003). Modelos urbanos y consumo de agua. El riego de jardines privados en la región metropolitana de Barcelona. Investigaciones Geográficas, 32,

AQ17 5-17. doi:10.14198/INGEO2003.32.02
15 $_{15}$ Domene, E., \& Saurí, D. (2006). Urbanization and water consumption: Influential factors in the metropolitan region of Barcelona. Urban Studies, 43, 1.605-1.623. doi:10.1080/00420980600749969

20 Domene, E., Saurí, D., \& Parés, M. (2005). Urbanization and sustainable resource use: the case of garden watering in the metropolitan region of Barcelona. Urban Geography, 268, 520-535. doi:10.2747/0272-3638.26.6.520

European Environment Agency. (2009). Water resources across Europe. Confronting water scarcity and drought. (EEA Report

AQ18 no 2). Copenhagen.

Fernández, S., \& Barrado, D. A. (2011). El desarrollo turísticoinmobiliario de la España mediterránea e insular frente a sus referentes internacionales (Florida y la Costa Azul): un análisis

AQ19 comparado. Cuadernos de Turismo, 27, 373-402.

Fernández, R., Ordovás, J., \& Herrera, M. A. (2011). Domestic gardens as water-wise Landscapes: A Case Study in Southwestern Europe. HorTechnology, 21, 616-623.

35 Fuentes, J. L. (1998). Técnicas de Riego. 3a Edición. Madrid: Ed. AQ20 Mundiprensa y Ministerio de Medio Ambiente.

Gaja, F. (2008). El tsunami urbanizador de la costa mediterránea.

AQ21 Scripta Nova, 12, 66-75.

40 Garcia, X. (2012). Nous processos d'urbanització $i$ consum d'aigua per a usos domèstics. Una exploració de relacions a l'ámbit

AQ22 gironí. (Doctoral thesis).

Garcia, X. (2014). Jardines privados y consumo de agua en las periferias urbanas de la comarca de la Selva (Girona).

AQ23 Investigaciones Geográficas, 61, 55-69. doi: http://dx.doi. org/10.14198/INGEO2014.61.04

Garcia, X., Llausàs, A., \& Ribas, A. (2014). Landscaping patterns and sociodemographic profiles in suburban areas: Implications for water conservation along the Mediterranean coast. Urban Water Journal, 11, 31-41. doi:10.1080/157306 2X.2012.758296

Gil, A., Hernández, M., Morote, A. F., Rico, A. M., Saurí, D., \& March Corbella, H. (2015). Tendencias del consumo de agua potable en la Ciudad de Alicante y Área Metropolitana de Barcelona, 2007-2013. Hidraqua, Gestión Integral de Aguas de Levante

\section{5}

AQ24 S.A. y la Universidad de Alicante.

Gil, A., \& Rico, A. M. (2007). El problema del agua en la Comunidad Valenciana. Fundación de la Comunidad Valenciana Agua y

\section{A 2025 Progreso.}

Gössling, S. (2015). New performance indicators for water management in tourism. Tourism Management, 46, 233-244. doi:10.1016/j.tourman.2014.06.018

65

Hernández, M., Morales, A., \& Saurí, D. (2014). Ornamental plants and the production of nature(s) in the Spanish real estate boom and bust:The case of Alicante. Urban Geography, 35,71-85. doi: 10.1080/02723638.2013.871813
Hernández, M., Rico, A. M., \& Juárez, C. (2010). Conflicts over water and land use on the coastline of the region of Valencia: Agriculture versus the urban city. In C. Brebbia, S. Hernández, \& E. Tiezzi (Eds.), The suistainable city. Urban regeneration and suistainability (pp. 405-417). WIT Press.

Hof, A., \& Wolf, N. (2014). Estimating potential outdoor water consumption in private urban landscapes by coupling high-resolution image analysis, irrigation water needs and evaporation estimation in Spain. Landscape and Urban Planning, 123, 61-72. doi:10.1016/j.landurbplan.2013.12.010

Huete, R., Mantecón, A., \& Mazón, T. (2008). ¿De qué hablamos cuando hablamos de turismo residencial? Cuadernos de Turismo, 22, 101-121.

Larson, K. L., Casagrande, D., Harlan, S. L., \& Yabiku, S. T. (2009). Residents' yard choices and rationales in a desert city: Social priorities, ecological impacts, and decision tradeoffs. EnvironmentalManagement, 44,921-937. doi:10.1007/00267009-9353-1

Loh, M., \& Coghlan, P. (2003). Domestic water use study: Perth, Western Australia 1998-2001. Perth:Water Corporation.

Lowry, J., Ramsey, R. D., \& Kjelgren, R. K. (2011). Predicting urban forest growth and its impact on residential landscape water demand in a semiarid urban environment. Urban Forestry \& Urban Greening, 10, 193-204. doi:10.1016/j.ufug.2011.05.004

March, H., Saurí, D., \& Rico, A. M. (2014). The end of scarcity? Water desalination as the new cornucopia for Mediterranean Spain. Journal of Hydrology, 519, 2.642-2.652. doi:10.1016/j. jhydrol.2014.04.023

Monreal, J. (2001). Un nuevo mercado turístico: jubilados europeos en la región de Murcia. Murcia: Universidad de Murcia.

Morote, A. F. (2014). Tipologías urbano-residenciales del litoral de Alicante: repercusiones territoriales. Ciudad y Territorio. Estudios Territoriales, XLVI, 181, 431-443.

Morote, A. F., \& Hernández, M. (2014). Jardines y urbanizaciones, nuevas naturalezas urbanas en el litoral de la provincia de Alicante. Documents d'Anàlisi Geogràfica, 60, 483-504. doi:10.5565/rev/dag.122

Morote, A. F., \& Hernández, M. (2016a). Urban sprawl and its effects on water demand: A case study of Alicante, Spain. Land Use Policy, 50, 352-362. doi:10.1016/j.landusepol.2015.06.032

Morote, A. F., \& Hernández, M. (2016b). Jardines y patrones de ajardinamiento en las urbanizaciones del litoral de Alicante. Boletín de la Asociación de Geógrafos Españoles, 70, 31-56. doi: 10.21138/bage.2161

Morote, A. F., Saurí, D., \& Hernández, M. (2016). Residential tourism. swimming pools and water demand in the Western Mediterranean. Professional Geographer. doi:10.1080/003301 24.2015.1135403

Navalón, R. (1995). Planeamiento urbano y turismo residencial en los municipios litorales de Alicante. Instituto de Cultura Juan Gil-Albert.

Padullés, J., Vila, J., \& Barriocanal, C. (2014a). Maintenance, modifications, and water use in private gardens of Alt Empordà, Spain. HortTechnology, 24, 374-383.

Padullés, J., Vila, J., \& Barriocanal, C. (2014b). Examining floristic boundaries between garden types at the global scale. Investigaciones Geográficas, 61, 71-86. doi:10.14198/ INGEO2014.61.05

Parés, M. (2005). Espai public enjardinat: impactes ambientals, model urbà i individualització a la Regió Metropolitana de Barcelona. Documents d'Anàlisi Geogràfica, 45, 91-109. 
Parés, M., Domene, E., \& Saurí, D. (2004). Gestión del agua en la jardinería pública y privada de la Región Metropolitana de Barcelona. Boletín de la Asociación de Geógrafos Españoles, 37,

AQ35 223-237.

Parés, M., March, H., \& Saurí, D. (2013). Atlantic gardens in Mediterranean climates: Understanding the production of suburban natures. International Journal of Urban and Regional Research, 37, 328-347. doi:10.1111/j.1468-2427.2012.01118.x

Parés, M., Saurí, D., \& Domene, E. (2006). Evaluating the environmental performance of urban parks in Mediterranean 15 cities: An example from the Barcelona metropolitan region. AQ36 Environmental Management, 38, 750-759.

Pujol, I. (2000). Mètode per âl càlcul de les necessitats diàries AQ37 d'aigua. Regaverd. Inédito.

Raya, P., \& Benítez, J. J. (2002). Concepto y estimación del turismo 20 residencial: aplicación en Andalucía. Papers de Turisme, 31, AQ38 67-89.

Renwick, M., \& Archibald, S. (1998). Demand side management policies for residential water use: Who bears the conservation

AQ39 burden? Land Economics, 74, 343-359.

Rico, A. M., \& Hernández, M. (2008). Ordenación del territorio, escasez de recursos hídricos, competencia de usos e intensificación de las demanda urbano-turísticas en la Comunidad Valenciana. Documents d'Anàlisi Geogràfica, 51,

\section{AO40 79-109.}

Rico, A. M., Olcina, J., \& Saurí, D. (2009). Tourist land use patterns and water demand: Evidence from the Western Mediterranean. Land Use Policy, 26, 493-501.

Robbins, P. (2012). Lawn people: How grasses, weeds, and chemicals make us who we are. Temple University Press.

Rovira, A. (2011). Atlas socio-comercial de la Comunitat Valenciana 2009. Valencia: Generalitat Valenciana y Consejo de Cámaras Oficiales de Comercio, Industria y Navegación de AQ42 la Comunidad.
Salvà, P. (2002). Foreign immigration and tourism development in Spain's Balearic Islands, Tourism and migration: New relationships between production and consumption. Londres: Kluwer Academic.

Salvati, L., Ridolfi, E., Zambon, I., Serra, P., \& Saurí, D. (2015). Swimming pools as indicator of urban sprawl: An exploratory analysis in a Mediterranean City. International Journal of Environmental Research, 9, 1325-1332.

Saurí, D., Parés, M., \& Domene, E. (2009). Changing conceptions of sustainability in Barcelona's public parks. The Geographical Review, 99, 23-36.

St. Hilaire, R., Spinti, J. E., Van Leeuwen, D., \& Smith, C. (2003). Lansdcape preferences and attitudes toward water conservation: A public opinion survey of homeowners in Las Cruces, New Mexico. New Mexico, NM: New Mexico State University.

Swyngedouw, E. (1999). Modernity and hibridity: Nature, regeneracionismo, and the production of the Spanish waterscape, 1890-1930. Annals of the Association of American Geographers, 89, 443-465.

Swyngedouw, E. (2004). Social power and the urbanization of water. Oxford: Oxford University Press.

Swyngedouw, E. (2015). Liquid power. Contested hydromodernities in twentieh century Spain. Cambridge, MA: The MIT Press.

Swyngedouw, E. (2016). From Spain's hydro-deadlock to the desalination fix. Water International, 41, 54-73. doi:10.1080/ 02508060.2016.1107705

Timmins, C. (2002). Measuring the dynamic efficiency costs of regulators preferences: Municipal water utilities in the arid West. Econometrica, 70, 603-629.

Vera, J. F. (1987). Turismo y urbanización en el litoral alicantino. Alicante: Diputación Provincial de Alicante. 